\title{
The Design of a Tool to Measure the Effectiveness and Efficiency of Users Towards the Application of Polisiku Application
}

\author{
Eko Setiawan ${ }^{1 . *}$ Wiza Yunifa ${ }^{1}$ \\ ${ }^{1}$ Information Systems Study Program, Politeknik PalComTech Palembang \\ "Corresponding author. Email: eko.setiawan@palcomtech.ac.id
}

\begin{abstract}
Polisiku the application is used as a means of police service against msyarakat. A review of the utilization of my police application is necessary to measure the effectiveness and efficiency of the user. The purpose of this research is to design a tool measuring the effectiveness and efficiency of users of the Polisiku application. This study uses dimensions of effectiveness and efficiency based on ISO 2196 which is irrigated from five criteria consisting of Task Effectiveness, Error Frequency, Task Completion, Compliance, Resource Utilization. The measuring instrument used in this study was a questionnaire with the Measurement scale type used in this study is the likert scale. The system's effectiveness and efficiency measuring tool is based on the ISO 9126 model. This measuring instrument will be used in further research on measurement and analysis of the effectiveness and efficiency of the Polisiku application.
\end{abstract}

Keywords: Poliaiku Application, Tool, Users

\section{INTRODUCTION}

Polisiku the application is used as a means of police service to the community. The app has also supported eleven police officers' priorities towards a professional, modern and well-known police service as well as a community-limited police service. [1]. A review of the utilization of my police application is necessary to measure the effectiveness and efficiency of the user. The effectiveness of a software can be measured by factors such as job effectiveness, error frequency, and job completion [2]. Effectiveness is the main element to achieve the goals or objectives that have been determined in each organization, activity or program [3]. In a nutshell the effectiveness of measurement in the sense of achieving a previously determined goal. Effectiveness is the relationship between output and goals to be achieved, operational activities are said to be effective if the process of achieving the objectives and the final goal of the policy [4]. While efficiency can be measured from time factor, resource utilization and suitability. Efficiency is closely related to the concept of productivity, efficiency measurement is carried out using a comparison between the output produced against the input used [5]. Efficiency is the best comparison between input and output (the result between profit and resources used), as are the optimal results achieved with limited use of resources [6].

Polisiku the application has never been measured before after this application was implemented. therefore researchers take measurements using variables of effectiveness and efficiency based on ISO 9126. The application of Polisiku application with a degree of effectiveness and efficiency can determine the success of the application of Polisiku itself. The higher the level of effectiveness and efficiency, the more functionality and usability of the application [7]. This study uses variables used consisting of Task Effectiveness, Error Frequency, Task Completion, Compliance, Resource Utilization. Uses variable effectiveness and efficiency based on ISO 9126. The type of measurement scale used in this study uses likert scale. The likert scale is chosen because it is used to measure the attitude, opinion and perception of a person or group about a state [8]. This measuring instrument is used in subsequent research by measuring the effectiveness and efficiency of users of the Polisiku application.

\section{METHODOLOGY}

As for the methods that researchers used in this study, it can be seen in the following steps:

1. To observe the implementation of Polisiku application by the public as a respondent in this study.

2. Conduct a library study of effectiveness and efficiency based on ISO 9126.

3. Designing effectiveness and efficiency tools based on ISO 9126.

4. Conclude the results of the study and advise on further research in line with this research. In figure 1. Is a research flow. 


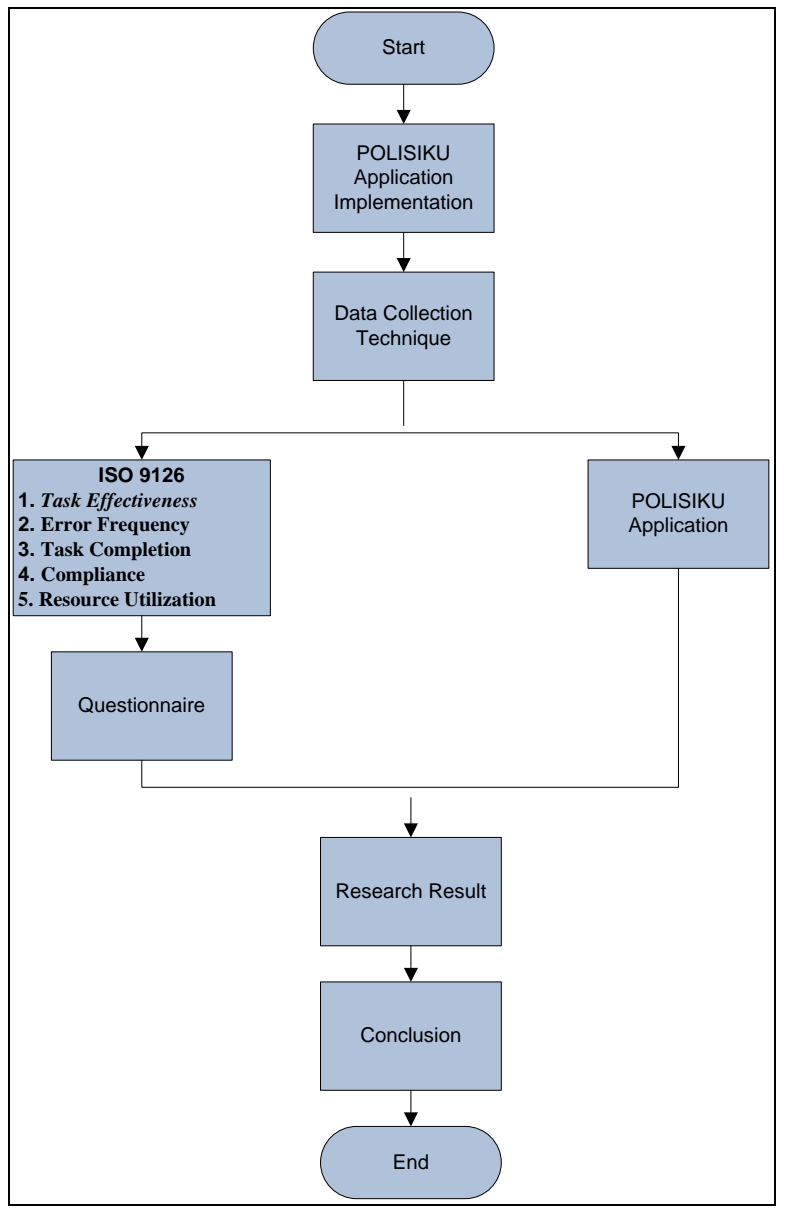

Figure 1. Flowchart

\section{RESULT AND DISSCUSSION}

The ISO 9126 model for effectiveness and efficiency dimensions consists of five criteria, including: Task Effectiveness, Error Frequency, Task Completion, Compliance, Resource Utilization. these five criteria have strong values and are highly compliant to measure the level of effectiveness and efficiency.

1. Task Effectiveness

Task Effectiveness contained in ISO 9126 has a sense that the proportion of goals of a task is achieved correctly. The operational definition of task effectiveness is how much percent of tasks are achieved easily or correctly.

2. Error Frequency

Error Frequency contained in ISO 9126 has a sense of how many times the error or error of the system or application when input or uploading data.

3. Task Completion

The task completion contained in ISO 9126 has a sense that the percentage of data input has been completed.

\section{Compliance}

Internal metrics related to efficiency indicate a set of attributes to assess the feasibility of a software that meets user organization standards, conventions or regulations in relation to efficiency.

5. Resource Utilization

Built-in resources that demonstrate a set of attributes to predict the utilization of hardware resources with computer systems including software products during testing or operation.

The measuring instruments designed in this study are created by formulating questions or statements using existing references. Of the five criteria are spelled out again into sub criteria. The sub kritria can be a question or question that is answered. Questions or alignment can be seen in table 1 .

Table 1. Measuring Instrument Statement

\begin{tabular}{cl}
\hline No & \\
\hline 1. & Task Effectiveness \\
1.1 & PoliceKu application complaints service registration can be answered faster and on time \\
1.2 & Public service registration on PolisiKu application can be done well \\
1.3 & Public service registration on PoliceKu application can be done correctly \\
2. & Error Frequency \\
2.1 & No link error in PoliceKu application \\
2.2 & Clear message on any menu that errors \\
2.3 & No menu that does not respond \\
2.4 & No empty menu \\
3. & Task Completion \\
3.1 & PoliceKu application page loading process faster \\
3.2 & PoliceKu application menu loading process faster \\
3.3 & Faster loading of registration forms \\
4. & Compliance \\
4.1 & There is a Police Call Center menu \\
4.2 & Service tools displayed in a decent format \\
4.3 & The information presented on the PoliceKu application is clear \\
4.4 & Polisiku the service menu is easy to understand \\
4.5 & An interesting look at the Polisiku the application
\end{tabular}




\section{Resource Utilization}

5.1 Be in GPS mode and connect to Google Map when accessing the PoliceKu application

5.2 Gps location accuracy in good condition

5.3 Users can activate GPS properly and can integrate with Google Map Description

$1 \quad$ Please Write down all complaints using the Polisiku application!

$2 \quad$ What makes you want to stick with this application?

3. Would you recommend this app to your friends and family? If so, give me a reason!

$4 \quad$ Please Write suggestions to improve the quality of service in this app for its users!

The type of measurement scale used in this study is the likert scale. This scale is used because it can measure attitudes, opinions and perceptions of a person or group about a state. The design of this measuring instrument uses four alternative answers that feel pali right to show the respondent's original attitude. The type of answer option in the score. Table 2 is an assessment of the likert scale answer options.

Table 2. Likert Scale Answer Option Assessment

\begin{tabular}{cc}
\hline Context & Value \\
\hline Very Agreeable & 4 Point \\
Agree & 3 Point \\
Disagree & 2 Point \\
Strongly Disagree & 1 Point \\
\hline
\end{tabular}

Researchers omitted the neutral question because it made it easier for researchers to see the attitudes of the actual respondents. If we use a likert scale with five alternative answers the results become err, which occurs in the field as a large number of respondents will fill in neutral, if not very understanding of the questions or statements asked. For such data includes independent or independent data, where the answers of one respondent have no influence or are not influenced by the answer of the other respondent. The result of the design of this measuring instrument is called kueisoner. Kusioner is used as a primary data collection tool by using survey methods to obtain respondents' opinions [9]. In addition to containing questions and questions in this questionnaire, alternative answers are given this score and measuring instrument also contains, the intent and purpose made from this questionnaire, and the respondent's data as an analysis of the respondent's criteria data. This questionnaire will be spread using google form to respondents. The design of the effectiveness and efficiency measuring instrument can be found in the following image :

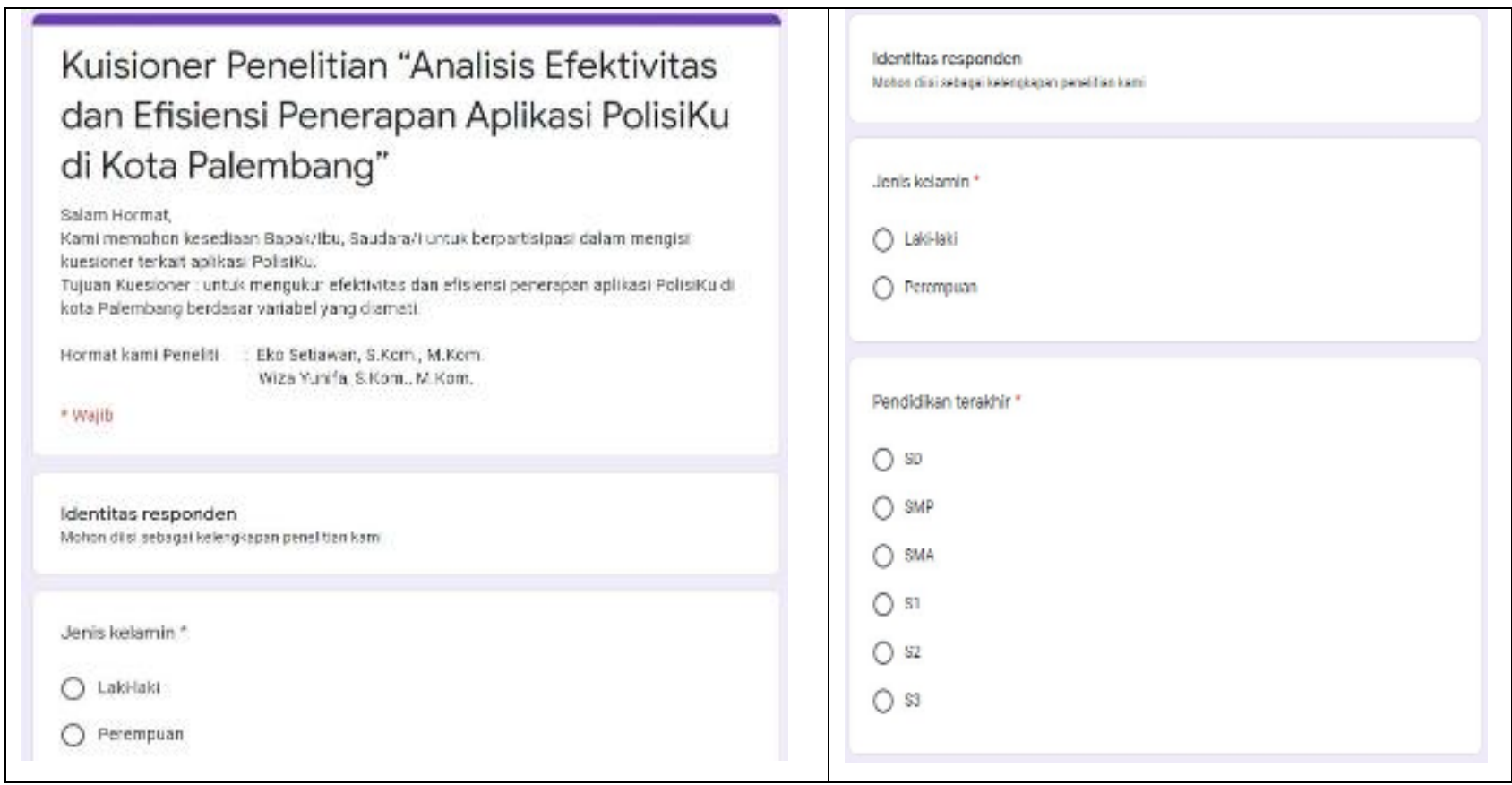




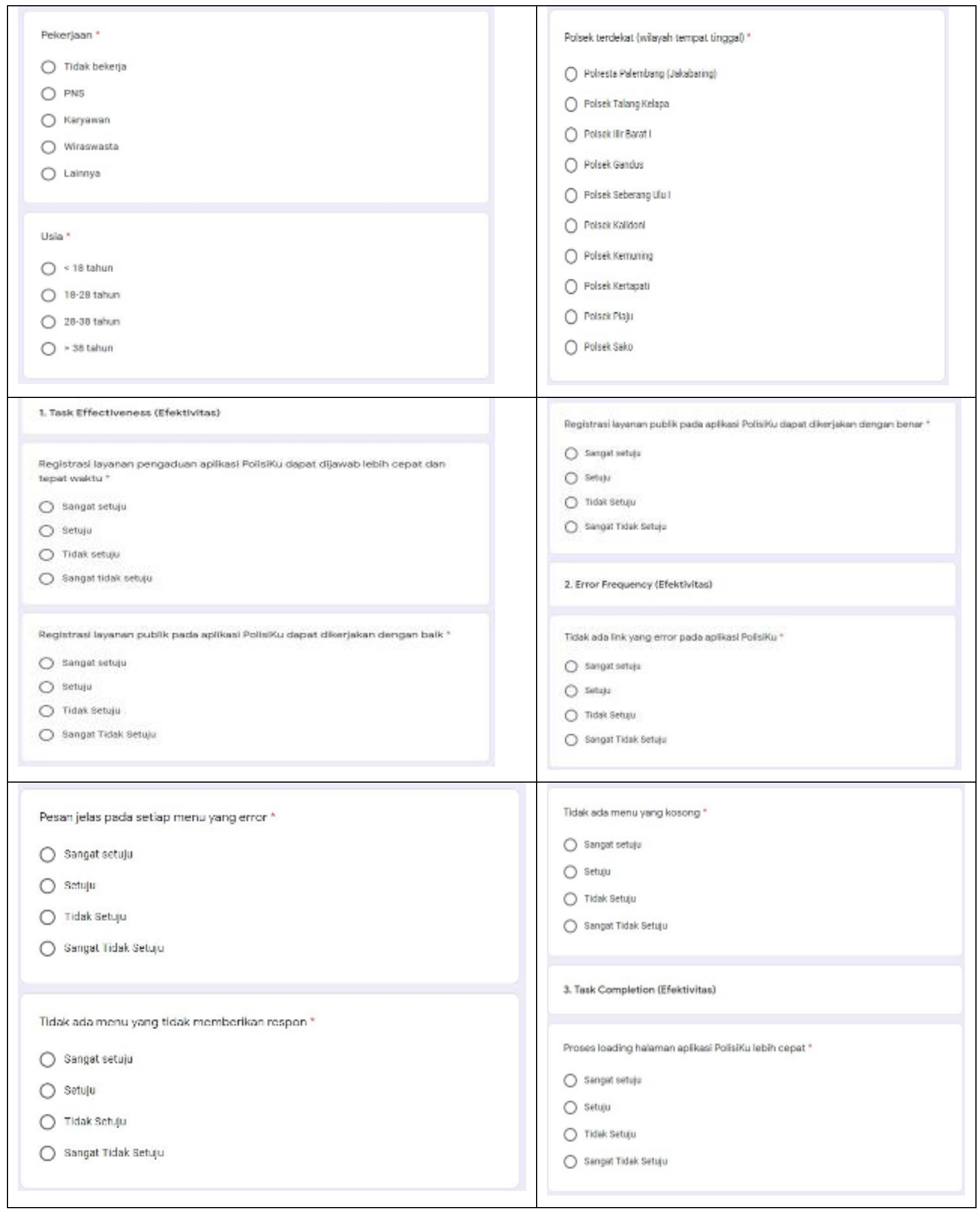




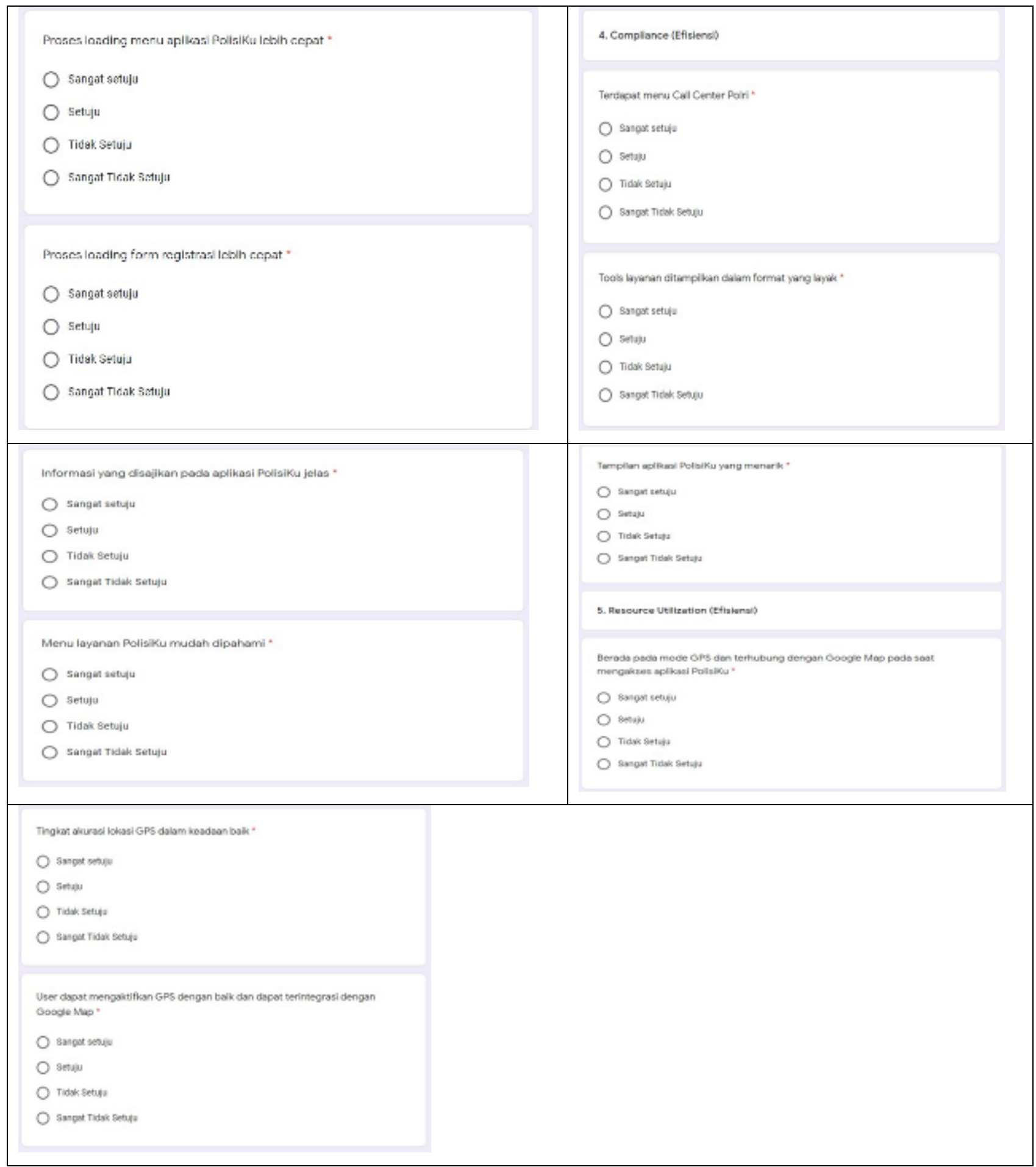

Figure 2. Instrument Statement

\section{CONCLUSION}

The system's effectiveness and efficiency measuring tool is based on the ISO 9126 model. This measuring instrument will be used in further research on measurement and analysis of the effectiveness and efficiency of the Polisiku application.

\section{REFERENCES}

[1] Prabowo, T. L. \& Irwansyah. 2018. Media Komunikasi Digital PolisiKu: Pelayanan Publik Polri kepada Masyarakat. Jurnal Studi Komunikasi. Vol. 2, Ed 3, November 2018, Page. 382-402.

[2] Yuniastari S, Nil Luh Ayu Kartika dan Wiyati, Ratna Kartika. 2015. Pengukuran Tingkat 
Efektivitas dan Efisiensi Sistem Eresearch STIKOM Bali. Konfersi Nasional Sistem dan Informatika, 9-10 Oktober 2015, Hal. 562-568.

[3] Rifa'i, Bachtiar. 2013. Efektivitas Pemberdayaan Usaha Mikro Kecil dan Menengah (UMKM) Krupuk Ikan dalam Program Pengembangan Labsite Pemberdayaan Masyarakat Desa Kedung Rejo Kecamatan Jabon Kabupaten Sidoarjo. Jurnal Kebijakan dan Manajemen Publik. Vol. 1, No. 1, ISSN: 2303-341X, Hal. 130-136.

[4] Sumenge, Ariel Sharon. 2013. Anaslisis Efektifitas dan Efisiensi Pelaksanaan Anggaran Belanja Badan Perencanaan Pembangunan Daerah (BAPPEDA) Minahasa Selatan. Jurnal EMBA, Vol. 1, No. 3, Hal. 74-81.

[5] Mardiasmo. 2009. Akuntansi Sektor Publik. Andi. Yogyakarta.

[6] Perdanawati, Luh Putu Virra Indah, Rasmini, Ni Ketut, dan Wirama, Dewa Gede. 2014. Pengaruh Unsur-Unsur Kepuasan Pengguna Pada Efesiensi dan Efekjtivitas Kerja Pengguna Aplikasi Sistem Akuntansi Instansi di Satuan Kerja Pendidikan Tinggi di Provinsi Bali. E-
Jurnal Ekonomi dan Bisnis Universitas Udayana 3.8, Issn: 2337-3067, Hal. 478-493.

[7] Rifa'i, Bachtiar. 2013. Efektivitas Pemberdayaan Usaha Mikro Kecil dan Menengah (UMKM) Krupuk Ikan dalam Program Pengembangan Labsite Pemberdayaan Masyarakat Desa Kedung Rejo Kecamatan Jabon Kabupaten Sidoarjo. Jurnal Kebijakan dan Manajemen Publik. Vol. 1, No. 1, ISSN: 2303-341X, Hal. 130-136.

[8] Handayani, F. S. 2014. Pengukuran Tingkat Kepuasan Pengguna terhadap Web Student Portal Palcomtech. Jurnal Teknologi dan Informatika (Teknomatika). Vol. 4, No.1.

[9] Hartati E, Indriyani R, dan Trianingsih I. 2020. Analisis Kepuasaan Pengguna Website SMK Negeri 2 Palembang Menggunakan Regresi Linear Berganda. Jurnal Matrik. Vol.2, No. 1 Issn: 2476-9843, Hal.47-58 